\title{
HVMANITAS
}

\section{Investidura de Tales como Sophos em Atenas?}

Autor(es): Leão, Delfim

Publicado por: $\begin{aligned} & \text { Faculdade de Letras da Universidade de Coimbra, Instituto de Estudos } \\ & \text { Clássicos }\end{aligned}$

URL

persistente:

DOI: $\quad$ DOI:http://dx.doi.org/10.14195/2183-1718_62_2

Accessed : $\quad$ 26-Apr-2023 14:44:29

A navegação consulta e descarregamento dos títulos inseridos nas Bibliotecas Digitais UC Digitalis, UC Pombalina e UC Impactum, pressupõem a aceitação plena e sem reservas dos Termos e Condições de Uso destas Bibliotecas Digitais, disponíveis em https://digitalis.uc.pt/pt-pt/termos.

Conforme exposto nos referidos Termos e Condições de Uso, o descarregamento de títulos de acesso restrito requer uma licença válida de autorização devendo o utilizador aceder ao(s) documento(s) a partir de um endereço de IP da instituição detentora da supramencionada licença.

Ao utilizador é apenas permitido o descarregamento para uso pessoal, pelo que o emprego do(s) título(s) descarregado(s) para outro fim, designadamente comercial, carece de autorização do respetivo autor ou editor da obra.

$\mathrm{Na}$ medida em que todas as obras da UC Digitalis se encontram protegidas pelo Código do Direito de Autor e Direitos Conexos e demais legislação aplicável, toda a cópia, parcial ou total, deste documento, nos casos em que é legalmente admitida, deverá conter ou fazer-se acompanhar por este aviso. 
humanitas

Vol. LXII

2010 


\title{
INVESTIDURA DE TALES COMO SOPHOS EM ATENAS? ${ }^{1}$
}

\author{
DeLFiM F. LeÃo \\ Universidade de Coimbra
}

\section{Resumo}

Este ensaio combina dois tipos de abordagens distintas. Na primeira, faz-se uma análise das circunstâncias históricas que marcaram Atenas no período posterior à actividade legislativa de Sólon, até ao momento em que Damásias ocupou o posto de arconte e depois se manteve agarrado ao mandato, durante mais um ano e dois meses. Na segunda parte, é discutido o testemunho de Demétrio de Fáleron (citado por Diógenes Laércio, 1.22), segundo o qual Tales teria recebido o título de sophos pela primeira vez durante o arcontado de Damásias.

Palavras-chave: Tales, Sólon, Damásias, Demétrio de Fáleron, sophos.

\begin{abstract}
This study combines approaches of two different kinds. The first analyses the historical circumstances that marked Athens during the period immediately after Solon's legislation, until the moment when Damasias held the archonship, and then clung to office for one year and two months more. The second approach discusses the testimony of Demetrius of Phalerum (quoted by Diogenes Laertius, 1.22), according to whom Thales was named for the first time sophos during the archonship of Damasias.
\end{abstract}

Key-words: Thales, Solon, Damasias, Demetrius of Phalerum, sophos.

1 Agradeço a Livio Rossetti o facto de me ter chamado a atenção para o passo de Diógenes Laércio que será objecto de análise, bem como a sugestão de procurarmos abordar o assunto em dois estudos complementares, publicados ambos neste número de Humanitas. 


\section{Contexto histórico}

Segundo a tradição, Sólon teria empreendido uma longa viagem (apodemia) depois de terminar a sua actividade legislativa. ${ }^{2}$ Deve ser genuína a notícia das viagens que então empreendera ao Oriente, embora não se tenham dado todos os encontros registados pelas fontes. É o caso da visita a Creso, em Sardes, e a Âmasis, o último grande faraó da dinastia saíta, ambas improváveis em termos cronológicos. No entanto, parece bastante seguro que o legislador tenha passado pelo Egipto, como atesta a sua poesia. ${ }^{3}$ De resto e ainda segundo a tradição, Sólon teria conhecido aí o mito de Atlântida, e Plutarco (Sol. 26.1) chega mesmo a dar o nome dos sacerdotes que lho teriam contado. No entanto, sobre esta notícia, que deriva de Platão, ${ }^{4}$ recaem legítimas suspeitas de que não terá valor histórico. Teoricamente, as coisas podem ter-se passado da forma enunciada, mas também há fortes probabilidades de que Platão haja inventado todo o episódio a fim de conferir maior dignidade ao Atlantikos logos. ${ }^{5}$ Já quanto a um outro encontro, desta vez com Filocipro, afigura-se plausível a hipótese de ter ocorrido, uma vez que as dificuldades cronológicas não são insanáveis e a viagem encontra apoio na poesia de Sólon. ${ }^{6}$

Neste momento, porém, mais do que a identificação dos lugares por onde o legislador terá andado, interessa sobretudo tecer algumas considerações sobre as causas que levaram à apodemia. Tanto Heródoto, como o autor

2 Em 593 ou o mais tardar em 591, no caso de se admitir a tese de N. G. L. Hammond relativa ao lapso temporal que mediaria entre a implementação de medidas de emergência e a obra legislativa propriamente dita. Esta proposta é feita, inicialmente, num estudo de 1940, intitulado "The seisachtheia and the nomothesia of Solon", JHS 60: 71-83, e republicado, com acrescentos, em Hammond 1973: 145-169. Para uma análise desta questão, vide D. F. Leão 2001: 268-275, esp. 272-273.

3 Cf. frg. 28 West.

4 Cf. Ti. 21-27; Criti. 108d, 113a-b.

5 Assim crê K. A. Morgan 1998: 108-114, para quem o uso que o filósofo faz da figura do legislador se insere na dinâmica da exploração do tema da patrios politeia. Sobre a tradição, também de origem platónica (Ti. 21c-d), de que Sólon começara a compor em verso um relato sobre Atlântida, vide comentário de M. Manfredini e L. Piccirilli 1998: 279-280.

6 Frg. 19 West. Para um conspecto da discussão à volta do oikismos ('fundação') de Solos (em Chipre ou na Cilícia) vide H.-D. Reeker 1971: 102-103, que se pronuncia a favor da nova fundação de Solos em Chipre, tradição que parece de facto ser preferível. 
do tratado aristotélico Constituição dos Atenienses e Plutarco ${ }^{7}$ concordam em que a viagem ocorreu depois de terminada a actividade legislativa e que o seu móbil real terá sido a vontade de evitar pressões para alterar o código que Sólon acabara de implementar. ${ }^{8}$ Aceitam globalmente ainda que o legislador terá justificado a viagem invocando motivações secundárias, ora recreativas e culturais, ora de natureza comercial. Por último, todos fixam o período de ausência em dez anos e concordam em que os Atenienses se comprometeram, durante esse tempo, a respeitar as leis. ${ }^{9}$ Divergem, no entanto, relativamente ao prazo de validade das leis: Heródoto aponta somente dez anos, os mesmos da apodemia, o que faz pensar que deduzira esse número a partir do período de duração da viagem; a Constituição dos Atenienses e Plutarco coincidem, ao sustentarem que o vínculo se estendia por cem anos, o que equivaleria provavelmente a dizer que as leis estavam destinadas a uma durabilidade ilimitada. Apesar destas posições de princípio, o certo é que os anos que se seguiram ao arcontado de Sólon continuariam a ser marcados por um clima de forte agitação política. A constatação desta realidade não implica que as reformas tenham falhado, pois a constituição e as leis de Sólon irão permanecer praticamente inalteradas até à deposição de Hípias, em 510. Um tal cenário mostra, no entanto, que a pacificação social estava ainda longe de ser alcançada e que Atenas não se iria eximir à experiência de um governo autocrático.

As fontes disponíveis para a reconstituição deste período não são muito abundantes e levantam, com frequência, complexos problemas de harmonização de informações. Está fora dos objectivos deste estudo abordar essa complexa questão, pretendendo-se evocar somente as circunstâncias que marcaram um período concreto: o arcontado de Damásias e por causa da forma como se poderá articular com a tradição dos Sete Sábios em geral e com a figura de Tales em particular. Como ponto de partida, pode tomar-se o

$7 \quad$ 1.29; Ath. 11.1 e Sol. 25.6, respectivamente.

8 Inverosímil a versão de Diógenes Laércio (1.50), segundo o qual a apodemia se deu após a instauração da tirania de Pisístrato, pois está claramente ao serviço da ideia de que Sólon não poderia viver debaixo de um regime autocrático. Além disso, enfrenta insuperáveis dificuldades cronológicas, ao prever uma datação demasiado baixa para o ano da morte do legislador.

9 Heródoto é o mais peremptório, ao referir que 'estavam vinculados por solenes

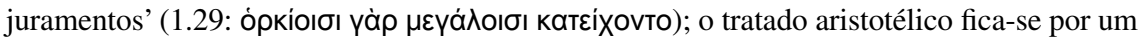

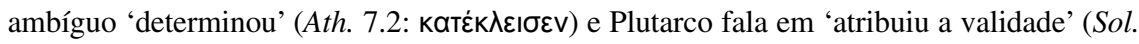

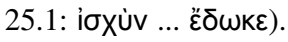


momento em que o autor da Constituição dos Atenienses refere o ambiente social que se vivia em Atenas quando Sólon partiu da Ática (Ath. 13.1-2):

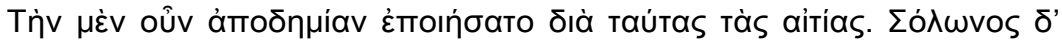

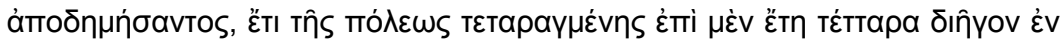

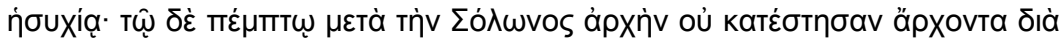

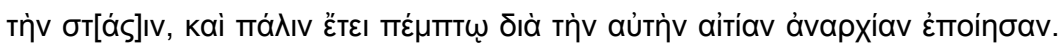

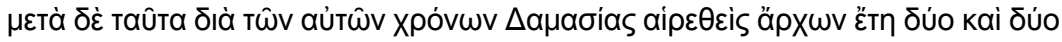

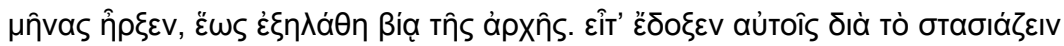

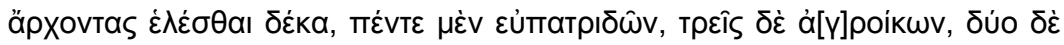

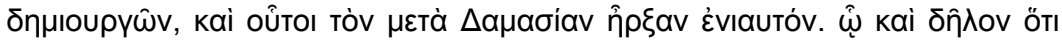

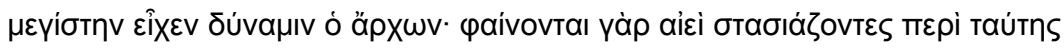
Tท̂s àpxn̂s.

Por conseguinte, Sólon realizou aquela viagem (apodemia) devido a esta ordem de razões. Quando ele se fez ao caminho, ainda a cidade andava agitada, mas os quatro anos seguintes decorreram com tranquilidade. Contudo, no quinto ano a seguir ao mandato de Sólon, não foi designado nenhum arconte, devido ao clima de guerra civil (stasis), e cinco anos mais tarde, pela mesma razão, esse cargo ficou também por ocupar (anarchia). Depois disto, volvido igual período de tempo, Damásias foi designado para arconte e manteve-se em funções durante dois anos e dois meses, até ser expulso à força do posto. Nessa altura, dado o clima de instabilidade social (stasiazein), decidiu-se proceder à escolha de dez arcontes: cinco entre os eupatridai, três entre os agroikoi e dois entre os demiourgoi; foram eles que governaram no ano a seguir a Damásias. Por aqui se vê que o arconte era quem detinha maior poder: mostram-no as forças políticas, que sempre disputaram este cargo.

O clima de agitação registado no passo está de acordo com a ideia de que Sólon - conforme o próprio legislador reconhece nos seus poemas ${ }^{10}$ - havia, de alguma forma, defraudado as expectativas que nele tinham sido colocadas, uns por esperarem alterações mais profundas, outros por acharem que tinha ido longe demais. Depois de alguns anos de relativa acalmia, há um claro sinal de instabilidade no facto de, por duas vezes, o cargo de arconte epónimo ter ficado por preencher. Tomando como referência o ano do arcontado de Sólon (594/3), esses dois períodos de anarchia teriam ocorrido a 590/89 e 586/5. Além disso, o autor do tratado regista o nome de certo 
Damásias, ${ }^{11}$ que começara por ocupar o cargo de arconte de forma legítima, talvez em 582/1, mas iria permanecer ilegalmente nesse posto durante dois anos e dois meses, portanto até aos primeiros dois meses de 580/79. Isto mostra que Damásias aspirava, com bastante probabilidade, à tirania, tomando como ponto de partida a projecção conseguida através do cargo de arconte, que era nessa altura uma magistratura com grande influência, conforme o autor do tratado salienta na parte final do passo em análise. ${ }^{12}$

Embora secundário para o assunto agora em discussão, é ainda assim pertinente sublinhar a forma como a anarchia se resolveu, através do recurso à indigitação de dez arcontes para substituir Damásias, de acordo com a seguinte composição: cinco eupatridai, três agroikoi e dois demiourgoi. À parte a discussão gerada à volta do significado deste colégio de magistrados e da exacta natureza social dos agroikoi e dos demiourgoi (que serão talvez de identificar com as classes ocupacionais dos 'camponeses' e dos 'artesãos' ou 'comerciantes', respectivamente), uma coisa ao menos afigura-se como segura: metade dos arcontes designados não pertencia ao grupo dos eupatridai. É possível que isso correspondesse a uma concessão momentânea destinada a acalmar os ânimos, mas também pode ser um indício da proporção de cidadãos não aristocratas que, após a reforma de Sólon, se situaria, ao menos, entre a classe dos hippeis. ${ }^{13}$ A ser assim, as reformas do legislador começavam a dar os primeiros frutos, em termos

11 Deve tratar-se de Damásias o Jovem, talvez familiar de um outro Damásias, arconte em 639/8, e por conseguinte será de crer que teria origem aristocrática. Vide T. J. Cadoux

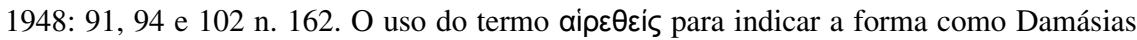
foi indigitado para o cargo tem levado alguns estudiosos a admitir a hipótese de que, nos tempos posteriores a Sólon, os arcontes eram eleitos de forma directa, entrando assim em contradição com a aplicação da klerosis ek prokriton, mecanismo que teria sido instituído por este legislador e que combinava a tiragem à sorte com a pré-selecção de um número reduzido de candidatos (cf. Ath. 8.1). P. J. Rhodes 1981: 182 não vê porém contradição

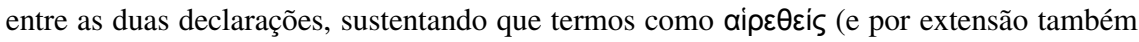
$\dot{\varepsilon} \wedge \dot{\varepsilon} \sigma \theta$ al, mais adiante) podem ter um sentido próximo de 'designar', em contextos em que não se especifica a forma como essa designação se efectua.

12 Esta observação serve também para estabelecer o confronto com a perda de influência política que caracterizará esta magistratura em meados do séc. V (cf. Ath. 22.5).

13 Vide Cadoux 1948: 102-103; H. T. Wade-Gery 1958: 100-104; R. Develin 1979: 464-465. Nesta composição dos dez arcontes não é forçoso ver um recuo às classes pré-solonianas (cuja natureza levanta sérias dúvidas), mas pelo contrário a confirmação da aplicabilidade do critério do rendimento às novas classes censitárias, como forma de qualificar o acesso ao poder. 
de recomposição do corpo cívico e de acesso ao poder, transformando lentamente o exclusivismo aristocrático. A Constituição dos Atenienses é omissa relativamente à forma como a designação do arconte epónimo continuou depois a efectuar-se. Deste silêncio, porém, não será improvável deduzir-se que tenha sido retomado o processo anterior à tentativa de golpe de Damásias. A composição dos dez arcontes indigitados para substituí-lo no poder indicará não que o cargo de arconte epónimo passava a um colégio de dez membros, mas antes que os cidadãos qualificados para ocupar essa magistratura se repartiriam, em termos proporcionais, pelos eupatridai, agroikoi e demiourgoi.

Os propósitos políticos de Damásias não foram, portanto, bem sucedidos, na medida em que não foi capaz de instaurar uma tirania duradoira, como aliás, cerca de duas dezenas de anos mais tarde, começaria por acontecer com Pisístrato. De resto, segundo uma tradição bastante difundida, o velho legislador ter-se-á oposto à primeira tentativa de Pisístrato para instalar a tirania, o que implica que, sendo embora de idade avançada, ainda estaria vivo em 561/0. ${ }^{14}$ Não há razões de peso para duvidar desta informação, uma vez que, nos seus poemas, o velho legislador avisa repetidamente os concidadãos contra a ameaça real da tirania, ${ }^{15}$ facto que mostra que ele estava a fazer uma leitura correcta das movimentações de Pisístrato, numa altura em que já teria regressado do seu afastamento voluntário de Atenas durante dez anos. Aliás, a aceitar-se o carácter genuíno da tradição, esta resistência política do velho legislador teria sido o seu último grande gesto público, dado que Sólon morreria pouco tempo depois. ${ }^{16}$

\section{Tales investido como sophos em Atenas}

É bem conhecido o facto de que, na tradição dos Sete Sábios, Sólon ocupa um posto central, destacando-se em particular, no leque de episódios ligados à sua figura, a célebre conversa entre Sólon e Creso, a propósito da noção de felicidade, que, sendo embora improvável do ponto de vista histórico, teve um amplo aproveitamento ético ao longo da antiguidade. ${ }^{17} \mathrm{De}$

14 Cf. Ath. 14.2; Plutarco, Sol. 30.6; Diógenes Laércio, 1.49; Valério Máximo, 5.3. Sobre a ambivalência da relação entre Sólon e Pisístrato, vide D. F. Leão 2008.

15 E.g. frgs. 11 e 33 West.

16 Entre 560 e 559. Cf. Plutarco, Sol. 32.3.

17 Sobre este aspecto em particular e dobre a tradição dos Sete Sábios como agentes de paideia, vide D. F. Leão 2010. 
momento, porém, interessam mais as notícias que procuravam ligar Sólon e Tales, em especial quando envolviam também a cidade de Atenas. Com efeito, Plutarco (Sol. 6) usa Hermipo como Mittelquelle para narrar um episódio que remontaria a Pateco. Segundo o relato, Tales teria dado ao legislador ateniense a falsa notícia da morte do próprio filho para demonstrar - a um Sólon acabrunhado pela angústia da perda - o motivo que o levara a não casar nem a querer prole, já que ambos eram fontes de canseiras. Embora a história seja, certamente, fictícia, conheceu ainda assim uma certa fortuna, por contribuir para a definição do ethos do sapiente. ${ }^{18} \mathrm{O}$ episódio narrado por Plutarco apresenta Sólon em Mileto, de visita a Tales, numa altura em que, em Atenas, o legislador gozava já da fama de ser homem sábio e com sentido de justiça (sophia, dikaiosyne), pelo que a implicação mais natural seria supor que o encontro em Mileto apareceria colocado durante a apodemia de Sólon. Essas viagens realizadas após a actividade legislativa dariam, aliás, o enquadramento mais natural para o encontro dos Sete Sábios e também para a tentativa de definir qual deles seria o mais importante. É esse, de resto, o contexto etiológico que está na base do bem conhecido episódio da trípode destinada a quem detivesse a primazia entre os sábios, mas que foi circulando entre os sapientes até ser finalmente dedicada a Apolo. Embora Tales não seja sempre o primeiro destinatário da trípode, ainda assim aparece muitas vezes como a grande figura de proa entre os sophoi. ${ }^{19}$

Ora é neste contexto do relacionamento entre sophoi que a ligação a Atenas e a Damásias encontra um testemunho de alguma forma surpreendente e que, por isso mesmo, importa discutir mais em pormenor. Diógenes Laércio é o responsável pela transmissão da notícia, cuja origem remontaria a Demétrio de Fáleron, um autor que inspira uma certa confiança (1.22):

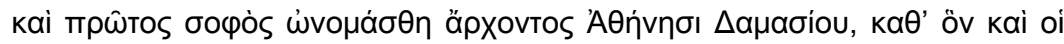

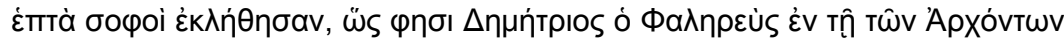
ávappạn̂.

Foi ele [Tales] o primeiro a ser nomeado sophos, em Atenas, durante o arcontado de Damásias. Foi também pela mesma altura que os Sete Sábios receberam esta designação, conforme sustenta Demétrio de Fáleron na Lista dos Arcontes.

18 Cf. Diógenes Laércio, 1.63, que cita Dioscórides a propósito desta mesma situação; Tzetzes, Chil. 5.359-375.

19 Os testemunhos relativos à circulação da trípode encontram-se reunidos em A. Martina 1968: 58-66. 
Este testemunho é bastante importante porque procura definir uma data específica para a investidura formal de Tales como sophos, bem como para a delimitação do grupo de Sete Sábios. Demétrio faz coincidir ambos os acontecimentos com o ano da celebração dos primeiros Jogos Píticos, conforme se pode deduzir da entrada correspondente no Marmor Parium. ${ }^{20}$ Dada a bem conhecida relação entre a moralidade délfica e a tradição dos Sete Sábios, tornam-se evidentes as vantagens de procurar associar os primeiros Jogos Píticos - dedicados a Apolo - à consagração da figura dos sapientes enquanto grupo. Essa datação de 582/1 teria, assim, algum interesse para entender a forma como a literatura sapiencial se foi enriquecendo com novos pormenores, mas dificilmente se lhe poderia dar um valor histórico seguro. Ora é precisamente neste particular que a referência a Damásias, numa obra em que Demétrio se dedicaria à reconstituição da lista oficial de arcontes atenienses, vem estimular algumas reflexões suplementares. Com efeito, não só a data destes eventos coincidiria com o ano do mandato legítimo de Damásias, como ainda a consagração de Tales enquanto sophos teria decorrido especificamente 'em Atenas' ('AӨńvnбı). ${ }^{21}$ Conforme se viu na primeira parte deste estudo, Damásias aspirava provavelmente à tirania, como se pode depreender do facto de ter permanecido no poder um ano e dois meses para além da normal duração do seu mandato de arconte. Tal situação pode levar a questionar o motivo pelo qual Damásias não terá sido deposto mal tenha dado mostras de querer prolongar o mandato, de forma ilegítima. As fontes nada dizem a esse respeito, mas talvez se possa imaginar que isso aconteceu devido ao facto de Damásias gozar, de alguma forma, de uma popularidade grande no termo do mandato, aura essa que acabaria mais tarde por alienar, forçando a sua expulsão. A aceitar-se esta possibilidade, ganha certa pertinência a hipótese de que, durante o primeiro ano de governo, ele teria feito alguma coisa de extraordinário, que houvesse deixado os Atenienses particularmente orgulhosos dos seus serviços. A consagração, em Atenas, de Tales como sophos poderia talvez corresponder a esse feito notável. De resto, há vários testemunhos que

20 Vide A. Mosshammer 1976: 165-166.

21 Esta interpretação do passo é determinante para as reflexões que se seguem. Entendendo, pelo contrário, que o testemunho indica somente que Damásias era nesta altura arconte 'em Atenas', nesse caso trata-se apenas de uma informação de cronologia relativa, que não implica uma ligação entre Tales e Atenas. No entanto, se Demétrio de Fáleron, que fora governante em Atenas, estava a fazer a Lista dos Arcontes atenienses, não faria sentido que tivesse de especificar que Damásias era arconte 'em Atenas'. 
indiciam que figuras como Epiménides e Anacársis teriam passado por Atenas no período que rodeou o arcontado de Sólon, eventualmente para surtir o mesmo efeito em termos de imagem pública. ${ }^{22}$

Por outro lado, se a ausência de Sólon provocada pela apodemia se prolongou durante dez anos, então ele poderia estar de regresso a Atenas precisamente pela mesma altura em que se teriam dado estes acontecimentos referidos por Demétrio. Expandindo um pouco mais a hipótese, não seria totalmente improvável imaginar que Sólon pudesse de alguma forma "apadrinhar", na própria pátria, a investidura de Tales como sophos, apesar de o legislador ateniense estar igualmente em condições de reclamar a mesma distinção. Este tipo de abnegação entre verdadeiros sophoi é o que motiva, de resto, que a trípode vá sendo sucessivamente remetida de sábio para sábio, até voltar ao ponto de partida e ser depois dedicada a Apolo. Por último, também se poderia ponderar a ideia de que, ao compreender finalmente as reais intenções de Damásias, Sólon lhe tivesse retirado o apoio, ajudando inclusive a depor o usurpador - um pouco à semelhança do que procuraria fazer mais tarde com Pisístrato.

Em suma: todas estas razões parecem dar validade probatória ao testemunho de Demétrio e à maneira como foi aqui interpretado. Mas a questão de fundo mantém-se: significa isso que esta reconstituição é um dado histórico objectivo ou, pelo contrário, que se trata apenas de uma realidade conveniente, que mais não serve que para ilustrar a forma como Demétrio terá raciocinado? A primeira hipótese é seguramente mais tentadora, mas, de um ponto de vista racional, a segunda será talvez mais prudente.

\section{Bibliografia citada}

CAdoux, T. J. (1948), "The Athenian archons from Kreon to Hypsichides", JHS 68: 70-123.

Develin, R. (1979), "The election of archons from Solon to Telesinos", AC 48: 455-468.

Hammond, N. G. L. (1940), "The seisachtheia and the nomothesia of Solon", JHS 60: 71-83 [= HAMMOND (1973) 145-162].

Hammond, N. G. L. (1973), Studies in Greek History. Oxford.

22 Sobre a problemática ligada à datação destas visitas, vide Leão 2001: 265-267 e 272-273. Para os testemunhos antigos relativos aos encontros entre Sólon, Epiménides e Anacársis, vide Martina 1968: 67-68 e 71-75, respectivamente. 
LEÃo, D. F. (2001), Sólon. Ética e política. Lisboa.

LEÃO, D. F. (2008), “A Sophos in arms: Plutarch and the tradition of Solon's opposition to the tyranny of Pisistratus", in J. R. Ferreira, L. Van der Stockt e M. do Céu Fialho (eds.), Philosophy in Society. Virtues and Values in Plutarch. Leuven, 129-138.

LEÃo, D. F. (2010), “A tradição dos Sete Sábios: o sapiens enquanto paradigma de uma identidade", in D. F. Leão, J. Ribeiro Ferreira e M. do Céu Fialho, Paideia e Cidadania. Coimbra, 47-110. (2 ${ }^{\mathrm{a}}$ ed. revista e aumentada)

Manfredini, M. e Piccirilli, L. (1998), Plutarco. La vita di Solone. Milano. (3 ${ }^{\text {a }}$ ed. revista)

Martina, A. (1968), Solon. Testimonia veterum. Roma.

Morgan, K. A. (1998), “Designer history: Plato's Atlantis story and fourth-century ideology", JHS 118: 101-118.

Mosshammer, A. (1976), “The epoch of the Seven Sages”, CSCA 9: 165-180.

REEKER, H.-D. (1971), “Solons Reisen”, A\&A 17: 96-104.

Rhodes, P. J. (1981), A Commentary on the Aristotelian Athenaion Politeia. Oxford. (1993, reimpr. com addenda)

WADE-GERY, H. T. (1958), Essays in Greek History. Oxford. 